\title{
Biopower from direct firing of crop and forestry residues in China: A review of developments and investment outlook
}

\author{
Jorrit Gosens ${ }^{a, b, c, *}$ \\ a Department of Energy and Environment, Division Environmental Systems Analysis, \\ Chalmers University of Technology, SE-41296 Göteborg, Sweden \\ b State Key Lab of Urban and Regional Ecology, Research Center for Eco-Environmental Sciences, \\ Chinese Academy of Sciences, Beijing 100085, China \\ c Section for Systems Analysis, SP Technical Research Institute of Sweden, SE-40022 Göteborg, Sweden
}

\section{A R T I C L E I N F O}

Article history:

Received 28 May 2014

Received in revised form

11 December 2014

Accepted 13 December 2014

Available online

\section{Keywords:}

China

Biomass power

Financial parameters

Net Present Value (NPV)

Investment outlook

\begin{abstract}
A B S T R A C T
This paper reviews developments in the direct-fired biomass power sector and provides an up to date investment outlook by calculating the Net Present Value of new investments, and the appropriate level of Feed-in-Tariff needed to stimulate future investment. An overview is provided of support policies, historical growth in installations, and main market players. A number of data sources is combined to build a database with detailed information of individual biopower projects. This data is used to describe technological and market trends, which are used in a cash flow model to calculate the NPV of a typical project. The NPV for new projects is estimated to be negative, and investment should be expected to stall without proper policy intervention. Increasing fuel prices, local competition over biomass fuel resources, lower than expected operational performance and a downturn in carbon markets have deteriorated the investment outlook. In order to ensure reasonable profitability, the Feed-In-Tariff should be increased, from the current level of $90.9 € \mathrm{MWh}^{-1}$, to between 97 and $105 € \mathrm{MWh}^{-1}$. Where possible, government organizations should help organize demand for the supply of heat. Local rural energy bureaus may help organize supply networks for biomass fuels throughout the country, in order to reduce seasonal and local fuel scarcity and price fluctuations.
\end{abstract}

(c) 2014 Elsevier Ltd. All rights reserved.

Abbreviations: CDM, clean development mechanism; CER, certified emission reduction; CF, capacity factor; CFB, circulating fluidized bed; CHP, combined heat and power; FIT, feed-in-tariff; GHG, greenhouse gas; MOA, ministry of agriculture; MSW, municipal solid waste; NBE, National Bio Energy Co., Ltd.; NDRC, National Development and Reform Commission; NPV, Net Present Value; VAT, value added tax.

* Department of Energy and Environment, Division Environmental Systems Analysis, Chalmers University of Technology, SE-41296 Göteborg, Sweden. Tel.: +4610516 6219.

E-mail addresses: jorrit@chalmers.se, jorrit@rcees.ac.cn.

http://dx.doi.org/10.1016/j.biombioe.2014.12.014

0961-9534/@ 2014 Elsevier Ltd. All rights reserved. 


\section{Introduction}

China has ambitious development plans for renewable energy, with an overall target of $15 \%$ of primary energy from renewables by 2020, and strong growth in renewable power generation [1]. Chinese installations of renewable forms of power have in recent years grown to be the world's largest [2], with particularly rapid increases in wind and solar PV installations (Table 1 ).

This development has been the subject of much research, with analysts looking into the role of e.g., the institutional framework [3-6], financial parameters of renewable power projects [7-10], and technological capabilities in the equipment manufacturing industry [11-15]. By comparison, biomass power has grown less rapidly (Table 1), and has received less attention, in particular concerning technological and financial parameters. A small number of analysts have previously commented on the cost and required subsidy levels for biomass power in China. These have been rather rough estimates [16,17] or, as we will demonstrate, require an update against recent developments in technological and financial parameters $[17,18]$.

This paper describes the recent development of China's biopower sector, focusing on developments in technological and financial parameters. These parameters are used to calculate 1) the Net Present Value of current investments in a typical Chinese biopower project, and 2) minimum levels of Feed-In Tariffs required to keep Net Present Value positive. Results of this exercise highlight low returns and high risks associated with current investment in biopower projects in China, explaining at least in part the relatively slow development of this form of renewable power.

This analysis is focused on 'crop and forestry residue based' biopower, a categorization used in Chinese policy to set it aside from biogas and MSW based forms of biopower. This is the largest form of biomass power in China, both in terms of current installations, and in future policy targets (Table 1). It is further focused on grid-connected applications ('main activity producers') as opposed to the in-house use of biopower ('autoproducers'). The latter type consists of numerous, small scale boilers, on which limited data is available. It is further not covered by government subsidies, nor is it expected to increase substantially in the foreseeable future [16,19]. Lastly, it is focused on direct-fired applications and ignores gasification, as grid-connected gasification is estimated to make up a few dozen MW at most [19]. For more information on these other technological pathways, please see the overviews provided by Zhao and colleagues [16] or the ERI [19].

\section{Method}

The economic desirability of a project can be evaluated using the Net Present Value method. This entails summing up positive and negative cash flows arising from the project. The cash flows are calculated on an annual basis, with future cash flows discounted to give their equivalent present value. The decision to invest is made when Net Present Value is at least zero. At this level, the internal rate of return (IRR) is equal to the discount rate [20].

Although the minimum IRR required for an investment to occur usually depends entirely on investor preference, Chinese regulations on investment in the power sector has set a benchmark IRR of $8 \%$ (post-tax) as feasible and reasonable [21] and this value is used to discount cash flows in the NPV estimation here. Project cash flows include investment, operational cost, production level, revenue and tax levels.

The proper (range of) values to be used in the NPV estimate have been determined through 3 data collection steps; 1) a review of policy documents and scientific literature on China's biopower sector; 2) compilation and analysis of a detailed database of individual Chinese biopower projects, followed by 3) a round of expert interviews correct or verify and enrich preliminary results from steps 1 and 2. A total of 19 experts were interviewed, including 7 academics, 2 market analysts, 5 representatives from industry and 5 representatives of government organizations.

The database of biopower projects in China (appended as Supplementary material) was compiled from the following data sources:

\section{CDM applications}

A large majority of Chinese biopower projects has applied for registration as a Clean Development Mechanism (CDM) project. Applications are publicly available [22] and include information on location, developer, capacity, boiler brand and

\section{Table 1 - Chinese renewable power capacity (MW), actual and targets, 2000-2020.}

\begin{tabular}{llllll} 
& 2000 & 2005 & 2010 & 2015 & 2020 \\
\hline Wind & 340 & 1,260 & 44,781 & 100,000 & 200,000 \\
Solar & 19 & 70 & 800 & $45,000^{\mathrm{a}}$ & 50,000 \\
Biopower (all), of which: & 1,100 & 2,071 & 3,952 & 13,000 & 3,000 \\
$\quad$ Crop and forestry residues based ${ }^{\mathrm{b}}$ & 1,000 & 1,741 & $1,000^{\mathrm{c}}$ & 2,000 & 24,000 \\
Biogas based & 0 & 30 & $500^{\mathrm{c}}$ & 3,000 & 3,000 \\
MSW based & 100 & 300 & 50,553 & 148,000 & 3,000 \\
Total, non-hydro renewables & 459 & 3401 & 966,410 & $1,465,000^{\mathrm{d}}$ & $1,750,000^{\mathrm{d}}$ \\
Total, all forms & 319,320 & 517,180 & $5.23 \%$ & $10.1 \%$ \\
Non-hydro renewables (\% of total) & $0.14 \%$ & $0.65 \%$ & $16.0 \%$ \\
\hline
\end{tabular}

Notes: grid-connected capacity only; a) the 12th Five Year Plan originally included a $21 \mathrm{GW}$ target for solar; this was increased to $35 \mathrm{GW}$ in early 2013 [78]; b) includes bagasse power; c) target rather than actual; d) forecast rather than target.

Sources: wind power: [57]; biopower: [16,55]; solar PV: [79]; totals: [55]; 2015 and 2020 targets: [1,80]. 
technical specifications, construction cost, estimated fuel consumption etc.

\section{Government subsidy reports}

The 'National Development and Reform Commission' (NDRC, China's ministry for economic and energy planning) periodically publishes data on power production and subsidies granted to individual renewable power projects [23]. These lists were used to verify which projects were operational, since when, and how much electricity was generated.

\section{Company reports and websites}

DP Cleantech, China's largest boiler designer, provided an up to date project reference list. Wuhan Kaidi, China's second largest boiler designer and biopower plant operator, publishes regular updates in the form of annual and quarterly reports on its website [24-26]. The database was further verified and updated with annual reports and news items available via websites of other project developers and boiler manufacturers.

The database contains a total of 236 projects. In figures presented in this paper, data is differentiated between 'operational' and 'planned' projects. 'Operational' projects were confirmed to be delivering power to the grid, using either NDRC reports, or annual reports or news items on company websites. 'Planned' projects are under construction, or have been announced in company reports or CDM project applications. The 236 projects in our database totaled 2019 MW in 2010 , or $58 \%$ of that years' operational capacity in crop and forestry residue based biopower in China, and $6173 \mathrm{MW}$, or $77 \%$ of the planned capacity in 2015 (see also Table 1, numbers include operational and planned projects).

Financial values throughout this paper are reported in euro, whilst most of the original data was reported in Chinese Yuan Renminbi (CNY). A single fixed exchange rate of 8.25 CNY $€^{-1}$ has been used (2012 average [27]). Inflation is corrected for using CNY based price indices [28].

\section{Results}

This section starts with background information on policy stimulus and guidance (Section 3.1), historical growth of installed capacity (Section 3.2), and project developers and boiler manufacturers active in China's direct fired biopower sector (Section 3.3).

The values and ranges of parameter values to be used in calculating project NPV are explored with a description of trends in technological parameters (Section 3.4), and the market environment (Section 3.5).

These results are combined to calculate the Net Present Value of new investment in a typical biopower project, and the required minimum level of Feed-In-Tariff to keep NPV positive (Section 3.6).

\subsection{Policy stimulus and guidance}

The Renewable Energy Law of 2005 has been credited as a milestone in Chinese government stimulus for RE [29]. This was a comprehensive framework law, with development targets and financial mechanisms detailed shortly after, in particular in the 'Medium and long term RE development plan' [30] and the 'Regulations on renewable energy price and costsharing management' [31].

Crop and forestry residue based power generation is targeted to reach $8 \mathrm{GW}$, with a production of 48 TWh, by 2015 . Biogas and MSW based forms make up the remainder for the overall biopower target of $13 \mathrm{GW}$ and 78 TWh by 2015.

In January 2006, a feed-in tariff (FIT) for biopower was set at $30.3 € \mathrm{MWh}^{-1}$ on top of the 'standard grid price' [31]. This standard is the price for power from de-sulfurized coal fired power generation, which is fixed at a government determined level and varies between 31.8 and $59.9 € \mathrm{MWh}^{-1}$ over different provinces (prices since 2011) [32]. Accounting for provincial level prices and installed biomass capacity, the average grid price received was $50.3 € \mathrm{MWh}^{-1}$, excluding $\mathrm{FIT}$, or $80.6 € \mathrm{MWh}^{-1}$ including FIT (incl. 17\% VAT) [32,33]. The FIT is awarded during the first 15 years of operation the project, the standard grid price applies afterwards [31].

Projects in operation prior to January 2006 were not eligible for the FIT. Projects that co-fire more than $20 \%$ conventional fuels have not been eligible either. Co-firing does not fit MOA's policy agenda for sustainable rural development, as ashes from co-fired plants cannot be returned to agricultural soils for fertilization, increasing already problematic levels of chemical fertilizer use. A lack of metering technology for establishing levels of co-firing has further raised concerns about possible fraud with reported levels of biomass use, and corresponding levels of FIT requested [19].

In 2010, the FIT was raised to $90.9 € \mathrm{MWh}^{-1}$ (total, not on top of standard grid price, and equal across all provinces) [34]. All projects eligible for the FIT introduced in 2006, including existing projects, have been receiving the increased FIT $[23,34]$.

The guideline for project size is between 12 and $30 \mathrm{MW}$ $[35,36]$. Larger turbines can be more fuel efficient, but the larger fuel collection area increases transport distances, which reduces environmental benefits.

To prevent competition over biomass resources, regulations suggest a maximum of one project per county, or to develop no further projects in a $100 \mathrm{~km}$ radius of an existing project [36]. This implies an exclusive resource collection area with a radius of $50 \mathrm{~km}$ for each project, which has been suggested to be sufficient for a $30 \mathrm{MW}$ project [37].

Policies have also addressed the need for compacted fuels (pellets or briquettes), including the establishment of an infrastructure for fuel collection, processing and distribution $[1,30,38]$. Key points of China's biomass power policies are summarized in Table 2.

\subsection{Installed capacity}

Since the enactment of the 'Renewable energy law' of 2005 and the 'Renewable energy price and cost-sharing management' of 2006 (Table 2), there has been a relatively rapid development of biopower plants. China's first biopower station started operations in December of 2006. Installations have accelerated to circa $1 \mathrm{GW}$ of additional capacity in recent years, and appear on track to meet the government target of 
Table 2 - Key points of Chinese policies for biomass power.

2005

Renewable energy law [81]

- State council will set RE development targets, lower level governments are to draft development plans accordingly

- Compulsory grid connection and full purchase of renewable power, gas and heat

- Periodically increased renewable energy surcharge for household use: initially $0.12 € \mathrm{MWh}^{-1}$ in 2006 ; has been $1,82 € \mathrm{MWh}^{-1}$ since September $2013[82,83]$.

2006

Renewable energy price and cost-sharing management [31]

- Biopower pricing determined as 1) a price agreed in tendered concessions; or 2) feed-in-tariff of $30.3 € \mathrm{MWh}^{-1}$ on top of standard grid price. Concession prices may not exceed standard FIT

- Co-firing projects not eligible if conventional fuels exceed $20 \%$ (heating value) of the fuel mix

2007

2008

Medium and long term RE development plan [30]

11th Five year plan for Renewable Energy [80]

- By $2010,10 \%$ of energy should come from renewables; by 2020 this should be $15 \%$

- Renewable portfolio standard (RPS): power companies with more than $5 \mathrm{GW}$ of generation capacity should have $3 \%$ of RE (excl. large hydro) by 2010 , and $8 \%$ by 2020

- Biomass power target of $5.5 \mathrm{GW}$, producing 24 TWh by 2010, and $30 \mathrm{GW}$ by 2020.

- Production of briquettes and pellets should reach 1 Mt by 2010 and 50 Mt by 2020

2007

Agricultural bioenergy industry development plan (2007-2015) [38]

- Production of briquettes and pellets should reach 20 Mt by 2015

- Develop briquetting technology and establish pilot programmes for crop straw collection, transport, storage and pre-processing. 2008

Strengthening the environmental impact assessment management of biomass power generation projects [35]

- Suggests higher capacity turbines, in principle no smaller than $12 \mathrm{MW}$

- Environmental impact assessment must consider effects of collection, transportation and storage of biomass fuel and other raw materials.

- Projects must adhere to standards for emissions to air 2010

Management of the construction of biomass power generation projects [36]

- Consider the availability of biomass resources in planning of biomass power projects.

- As a guiding principle, develop only one project per county or within a radius of $100 \mathrm{~km}$

- As a guiding principle, no projects of a scale of more than $30 \mathrm{MW}$

2010

Improved pricing policy for agriculture and forestry biomass power [34]

- Feed-in-tariff (FIT) equalized nation-wide and raised to $90.9 € \mathrm{MWh}^{-1}$

2012

12th Five Year Plan for renewable energy [1]

- Biopower target of $13 \mathrm{GW}$ by 2015, with an annual power generation of 78 TWh. No 2020 target is specified. For crop and forestry residue based power, the targets are $8 \mathrm{GW}$ and $48 \mathrm{TWh}$

- Production of briquettes and pellets should reach $10 \mathrm{Mt}$ by 2015

8 GW by 2015 (Fig. 1). In addition to the projects included in Fig. 1, there is circa $1700 \mathrm{MW}$ of bagasse power generation capacity installed in China's sugar cane processing plants $[16,19]$. This capacity is used to supply in-house power and heat demand, and is not expected to grow significantly in the foreseeable future. Other forms of crop and forestry residue based power generation, including e.g., gasification are very small in terms of installed capacity $[16,19]$.

\subsection{Project developers and boiler manufacturers}

\subsubsection{Project developers}

The developer and operator of China's first biopower plant is the National Bio Energy Co., Ltd. (NBE; now part of the State Power Group Co., ltd). NBE's expansion was a main driver for market growth in the following few years. In 2009, NBE operated $63 \%$ of the $901 \mathrm{MW}$ of operational biopower plants in

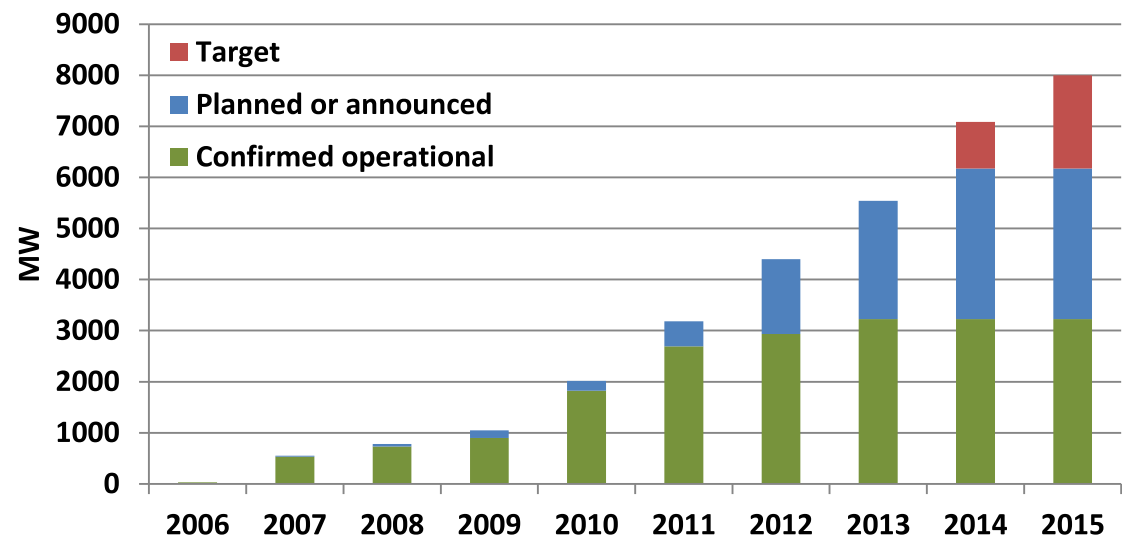

Fig. 1 - Cumulative capacity of direct-fired biopower projects in China. Notes: grid-connected applications only; 'Target' is the 12th Five Year Plan target for all forms of 'crop and forestry residues based biomass power', including gasification and bagasse power. Source: [33]. 
China. NBE remains the market leader today, with circa onethird of all biopower stations (Fig. 2).

The second largest developer is Wuhan Kaidi Electric Power Co., Ltd. (Kaidi). This company has traditionally been engaged in the design and turn-key development of coal-fired power plants. In recent years, it has specialized in environmental technologies related to power generation, including clean coal technologies, flue gas treatment and MSW incineration plants. In 2010, Kaidi opened its first biomass power station. By the end of 2013, it had 19 plants with a combined capacity of $518 \mathrm{MW}$ in (trial) operation, and another 26 in the planning phase (Fig. 2).

China's big state-owned power companies (the so-called 'Big 5: CPI, Datang, Guodian, Huadian and Huaneng), which are the largest developers of wind and solar projects [39], are relatively inactive in biopower generation (Fig. 2). Interviewees explained this as due to a preference for larger project sizes, and the better predictability of resources (wind speed and sunshine hours), when compared with biomass fuel supply and prices. The remainder of projects are developed and operated by a very diverse group of state owned and local utilities, operating between one and four projects each.

\subsubsection{Boiler designers and manufacturers}

DP Cleantech has been market leader since China's first biopower plant was constructed by NBE. DP Cleantech and NBE were subsidiaries of a mutual parent company called Dragon Power Group Co., Ltd. DP Cleantech designed NBE's power plants, with boiler manufacturing outsourced to Jinan Boiler Group, which was acquired by the Dragon Power Group in July of 2007 [40]. In 2010, Dragonpower split and NBE and DP Cleantech became independent companies. They remain each other's most important business partners, although both have diversified their supplier or client portfolio. Kaidi designs the boilers and rest of the power plants it operates itself, with boiler manufacturing outsourced to a number of domestic firms, including Hangzhou Boiler Grp., Jiangxi Jianglian and Suzhou Hailu. A third boiler brand used in a relatively large number of projects is Wuxi Huaguang. Technical details on boilers used in China's biopower projects are included in the database provided as Supplementary material with this article.

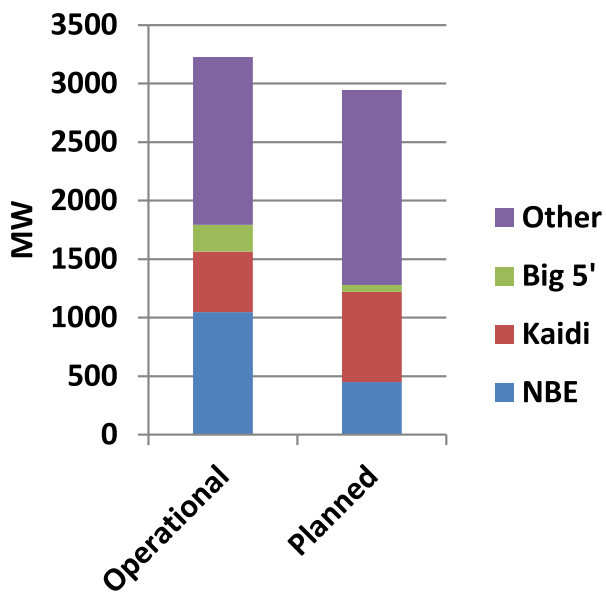

Fig. 2 - Operators of biopower projects in China. Data source: [33].

\subsection{Technological trends}

This section describes project scale, the use of either vibrating grate or circulating fluidized bed designs, as well as developments in boiler pressure, project construction cost and realized operational performance.

\subsubsection{Project scale}

China's biopower policies favor purely biomass fired power plants (see Section 3.1), which have traditionally been smaller scale plants (several to several dozen MW) [41]. Larger capacity boilers will be able to attain higher energy efficiency [42], but require a larger resource collection area, which increases fuel transport distance and cost, and reduces GHG reduction benefits [41]. The optimum size suggested by policy is between 12 and $30 \mathrm{MW}$ (see Section 3.1), and developers have generally adhered to this guideline (Fig. 3).

Compacting biomass fuels into pellets increases the energy and cost efficiency of long range fuel transport [43,44]. In 2012, total global pellet production was approximately $22.4 \mathrm{Mt}$, of which 8.2 Mt were traded internationally [43]. This has enabled larger scale biopower projects, e.g., the Tilbury power station (750 MW) and Drax power station (660 MW) in the U.K., both of which will rely largely on imported pellets $[45,46]$. Chinese imports and exports of pelletized fuels are estimated to be very limited [47].

Domestic pellet production was circa $3 \mathrm{Mt}$ in 2010 [43], and is targeted to reach $10 \mathrm{Mt}$ by 2015 [1]. Only part of these fuels is meant for use in power generation, however.

China's policy plans are strongly aimed at the production of biomass briquettes, which should replace coal and unprocessed biomass still commonly used in household stoves in rural China [38].

\subsubsection{Boiler design: grate firing or fluidized bed}

Two different designs for the combustion of biomass fuels have been used in China: water-cooled vibrating grate and Circulating Fluidized Bed (CFB). Both technologies have their respective advantages and disadvantages in the utilization of biomass fuels (for an overview, please see e.g., [48-50]). Between the two, CFB boilers have a greater need for a more constant fuel supply ([48,51]; an issue further dealt with in Section 3.4.5).

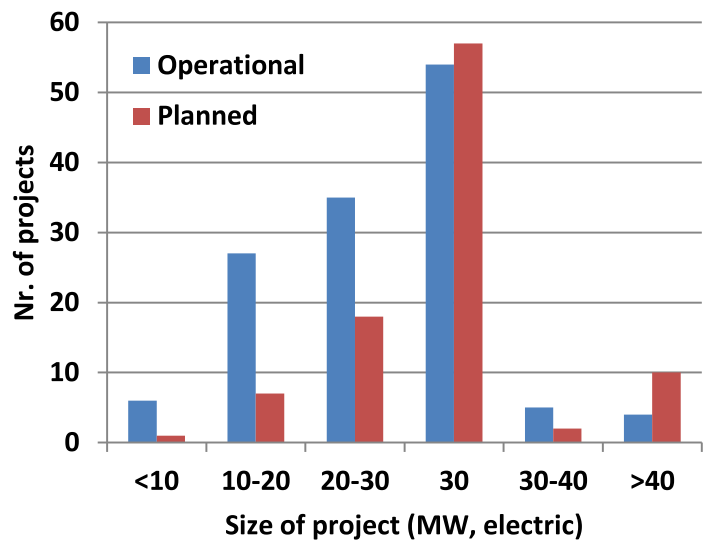

Fig. 3 - Scaling of direct-fired biopower projects in China. Data source: [33]. 
Three boiler brands active in China use a water-cooled vibrating grate design: DP Cleantech, Wuxi Huaguang and China Western Power. Remaining manufacturers use a CFB design. These manufacturers all have experience with coal fired boilers, and CFB is the most popular design in thermal power generation in China. Amongst others, this is because China has large amounts of coal with high sulfur content, and CFB boilers allow for cost-effective emission control of sulfur oxides, by mixing limestone in the fuel mixture [52].

\subsubsection{Boiler steam pressure}

Boilers that operate at higher pressure and temperature can achieve higher fuel efficiency but are more difficult to engineer and tend to be more costly. In biomass boilers, alkali and chloride corrosion is an issue in particular at higher temperatures and pressure [53]. Such boilers therefore require advanced, costly alloys with high resistance to such corrosion [53].

DP Cleantechs boilers, which were the most popular between '06 and '09, is a high pressure, high temperature design (9.2 $\mathrm{MPa}$ and $540{ }^{\circ} \mathrm{C}$ ). Domestic manufacturers have relied on low and medium pressure designs (ca. 3.8 and 5.3 $\mathrm{MPa}$ ) for several years. The first domestically produced high pressure boilers (ca. 9.2 MPa) came online late '10 and early '11 (Fig. 4). Kaidi has developed a super high pressure (13.3 MPa) CFB boiler, and uses it in six power plants that became operational over the course of 2013. Earlier power plants developed by Kaidi use its 5.3 MPa design [33]. Operators in China have continued to use a diverse mix of low, medium, and high pressure boilers (Fig. 4). Increased market share of domestic suppliers of low and medium pressure designs has led to a decrease of the average pressure of boilers used. The introduction of Kaidi's super-high pressure design in 2013 has reversed this trend (Fig. 4).

\subsubsection{Construction cost}

Construction costs for biopower projects in China have had a downward trend, from $1400 € \mathrm{~kW}^{-1}$ in '07 to circa $1150 € \mathrm{~kW}^{-1}$ in '12 (Fig. 5). Interviewees attributed the downward trend mostly to increased competition, i.e., more suppliers and a larger number of projects.
No demonstrable differences in cost were found between CFB of grate fired designs, or projects with different boiler pressures. Even Kaidi's super-high pressure design has costs close to the market norm of $1150 € \mathrm{~kW}^{-1}$ in '12 [33]. Despite the downward trend in recent years, interviewees indicated that a significant further decline would be unlikely.

\subsubsection{Operational performance}

Operational performance of a power plant can be reported as capacity factor, i.e., actual power production, divided by the amount of power that would have been produced if the plant constantly operates at full load.

Power production may be halted for routine maintenance. Maintenance is also needed in the case of equipment failure, and therefore depends on technological quality. Capacity factors can also be reduced by curtailment, i.e., when the grid operator has no need for power from a specific plant and denies it grid access. Lastly, production may be ceased when fuel is unavailable or priced at a level that does not allow for profitable production [54].

The Chinese policy target, of 48 TWh of production with $8 \mathrm{GW}$ of installed capacity, implies a capacity factor of $68.5 \%$. This is ambitious, as even coal fired power plants typically achieve a capacity factor of between 60 and 70\% (annual average, calculated on nameplate capacity), both in China and the US [55,56]. CDM applications for Chinese biopower projects predicted a capacity factor of $62.4 \%$ on average [33]. Actual operational performance has lagged behind either of these expectations. The average capacity factor was $55.0 \%$, with a wide variation in performance between individual projects (Fig. 6).

Interviewees indicated that curtailment was not an issue. Curtailment is a severe issue for wind power in China, due to the intermittency of production and limited transport capacity of power lines between generation and load centers [57]. Biopower is far less intermittent, and power plants are of smaller sizes and closer to load centers than wind farms are.

Technological choices did influence operational performance. Projects using grate firing designs performed significantly better than those using CFB boilers, at $62.9 \%$ versus $50.4 \%$, respectively [33]. Boilers from the three biggest brands

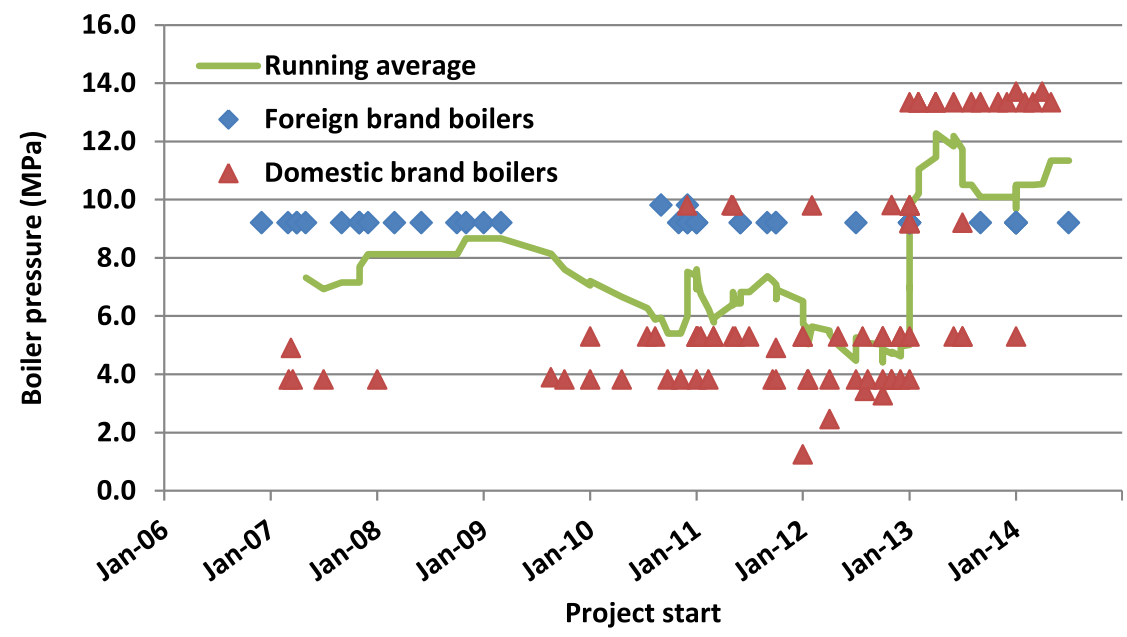

Fig. 4 - Steam pressure of biopower projects in China. Notes: includes operating and planned projects; includes 126 projects for which boiler pressure data was available. Data source: [33]. 


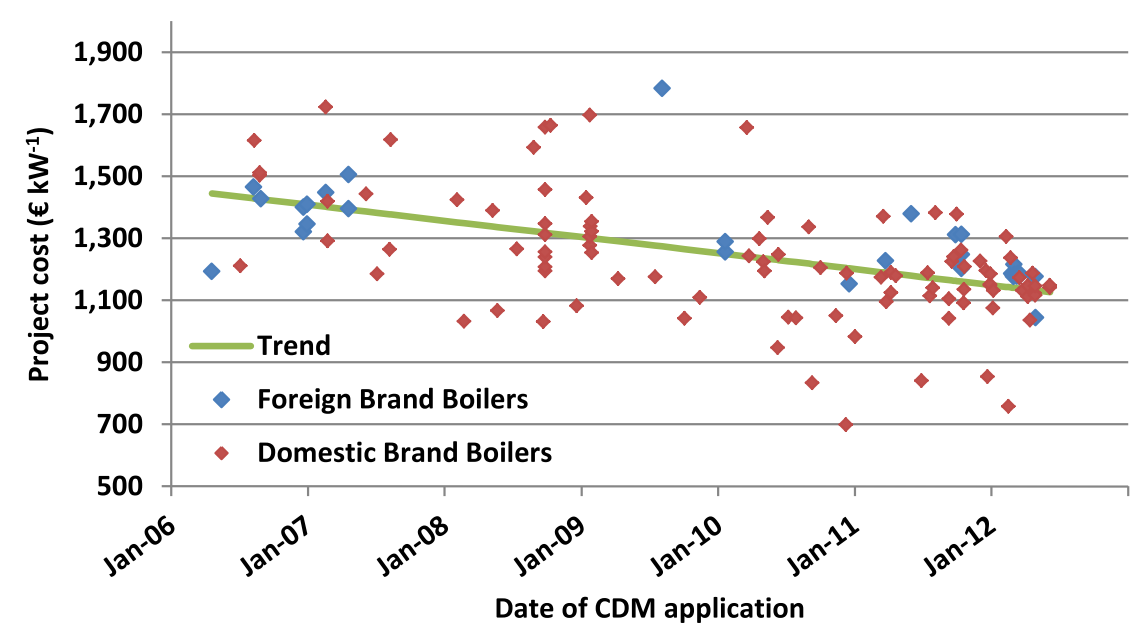

Fig. 5 - Construction cost of direct fired biopower projects in China. Notes: includes 163 projects for which construction cost data was available; note that the date is of the CDM application, not project start; inflation is corrected for using CNY price indices [28]. Data source: [33].

by market share outperformed those from other brands (Fig. 6). Nevertheless, each of these brands had strongly varying performance in different projects. Even amongst the projects using technology from DP Cleantech, arguably the most tested and matured technology in the Chinese market, a significant number of projects performed very poorly (Fig. 6). If this low capacity factor is indeed not due to poor technology, i.e., downtime due to maintenance requirements, fuel supply problems are likely an issue. This would be consistent with the observation that projects using CFB boilers perform more

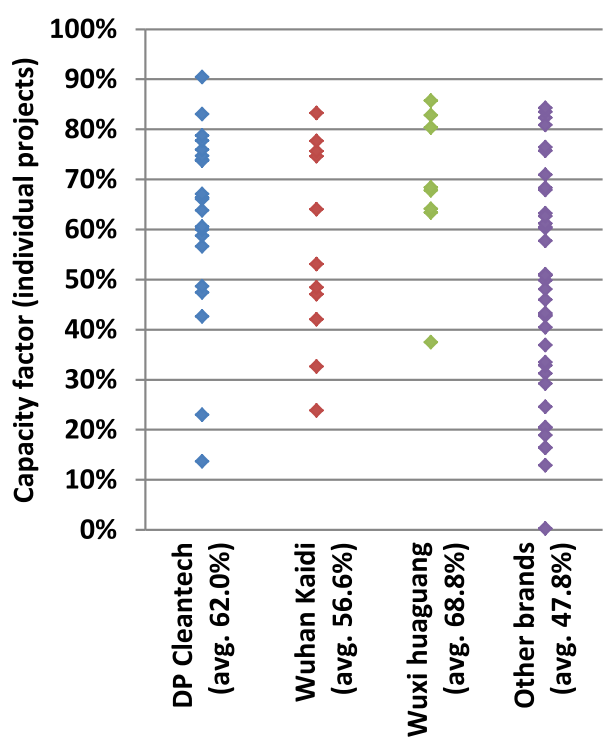

Fig. 6 - Capacity factor of individual biopower projects, by boiler brand. Notes: Capacity factor is operational performance data based on NDRC's subsidy report for the period Oct. '10 - Apr. '11 [23]. All projects were operational for the entire reporting period, as we included only those projects that were reported to be operational in the previous edition of the subsidy report as well. Data source: $[33,23]$. poorly. This type of boiler requires more constant fuel supply as these cannot easily operate at partial load, because the bed requires a minimal amount of heat input to maintain (optimal) combustion conditions [48,51]. Grate firing systems have no such requirements. Problems with fuel supply impacting operational performance was acknowledged by nearly all interviewees, and is further investigated in Sections 3.5.1 and 3.5.2.

\subsection{Market environment}

Here the aspects of the market environment that influence the financial performance of biopower projects are discussed, including fuel availability, fuel pricing, sales of heat, and sales of carbon credits.

\subsubsection{Fuel availability and competition}

The NDRC has assessed the availability of China's crop and forestry residues (Table 3; data is from 2008). Residue yield from agriculture was estimated at $816 \mathrm{Mt} \mathrm{y}^{-1}$, with a further $368 \mathrm{Mt}$ of forestry residues [19]. The most abundant crop residues are from corn $(265 \mathrm{Mt})$, rice $(205 \mathrm{Mt})$ and wheat (150 Mt) [19]. In addition to cotton stalks, these are also the most commonly used fuels in Chinese biopower plants [33]. These residues do have competing purposes; $500 \mathrm{Mt}$ is available for energy purposes, of which $129 \mathrm{Mt}$ is used for cooking and heating in rural household stoves (2008 data, Table 3). Although the traditional use of biomass remains substantial, total use has decreased by about $60 \%$ since 1990 [19,58]. This trend should be expected to continue with the replacement by more modern energy types, and result in more residues being freed up for utilization in biopower projects. The NDRC anticipates strong future growth in manure and MSW production but little growth in crop and forestry residue yield [19].

In 2012, biopower production would have required circa $39 \mathrm{Mt}$, or $8 \%$ of available biomass residues. China's 2020 targets for biopower would require circa $271 \mathrm{Mt}$, or $54 \%$ of all available residues (Table 4). 
Table 3 - Crop and forestry residues: quantity and uses.

\begin{tabular}{lc} 
Category & Amount (Mt) \\
\hline Total residues & 1,184 \\
Crop residues & 816 \\
Forestry residues & 368 \\
Unavailable for energy purposes & 684 \\
Animal feed & 211 \\
Stubble left in field & 133 \\
Fertilizer/soil improvement & 102 \\
Other & 31 \\
Forestry residues unavailable & 207 \\
$\quad$ for energy purposes & \\
Available for energy purposes & 500 \\
$\quad$ Unused crop residues & 210 \\
Household fuel use & 129 \\
Forestry residues & 161 \\
\hline a Includes biomass briquettes, see also Table 2. \\
Source: [19]. \\
$\quad$
\end{tabular}

Despite the relatively low fraction of available residues being used in biopower projects, there are increasing reports of fuel supply problems $[16,19,59]$. This is likely, at least in part, due to the geographic concentration of biopower projects.

The most abundant residue resources are found in the Northern and North-Eastern provinces, whilst these provinces, until the Feed-In-Tariff reform of 2010, had the lowest biopower prices [58,60]. Projects are currently strongly concentrated in the Eastern provinces (Fig. 7). More importantly, some areas have projects (or planned projects) in close proximity (less than $100 \mathrm{~km}$ ) to each other, in spite of regulations against such concentration [36] (see also Section 3.1). This will have led to competition over resources available from local agriculture.

It is worth pointing out that organizing of a fuel supply network should be expected to be a challenging task anywhere in rural China. A $30 \mathrm{MW}$ power plant will consume circa $250 \mathrm{kt} \mathrm{y}^{-1}$ of crop residue [33]. The average yield of corn, the most abundant residue, is $5.5 \mathrm{t} \mathrm{hm}^{-2}$ [61]. Residue (corn stalk)

Table 4 - Grop and forestry residue use for Chinese biopower targets.

\begin{tabular}{|c|c|c|c|}
\hline & 2012 & 2015 & 2020 \\
\hline \multicolumn{4}{|c|}{ Crop and forestry residue based biomass power } \\
\hline Capacity (MW) & $4,632^{\mathrm{a}}$ & 8,000 & 24,000 \\
\hline Production (TWh) & $22.3^{\mathrm{b}}$ & $48^{c}$ & $144^{c}$ \\
\hline Resource use (Mt) ${ }^{\mathrm{d}}$ & 33.4 & 72 & 216 \\
\hline \multicolumn{4}{|l|}{ Compacted fuels } \\
\hline Production (Mt) & 5 & 10 & 50 \\
\hline Resource use (Mt) & 5.5 & 11 & 55 \\
\hline Total resource use (Mt) & 38.9 & 83 & 271 \\
\hline Use as share of available & $7.8 \%$ & $16.6 \%$ & $54.2 \%$ \\
\hline \multicolumn{4}{|c|}{$\begin{array}{l}\text { a Assuming } 1.7 \mathrm{GW} \text { bagasse power and } 2.9 \mathrm{GW} \text { other crop and } \\
\text { forestry residue based biomass power (see Section 3.2). } \\
\text { b Assuming a capacity factor of } 54 \% \text {, see Fig. } 6 \text {. } \\
\text { c Assuming a capacity factor of } 68.5 \% \text { as targeted by policy [84]. } \\
\text { d Assuming resource use of } 1.5 \mathrm{t} \mathrm{MWh}^{-1} \text { (average reported in CDM } \\
\text { applications [33]). } \\
\text { e Resource use as suggested by Ref. [19]. }\end{array}$} \\
\hline
\end{tabular}

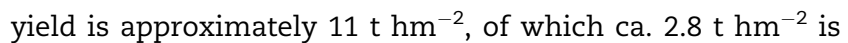
available for biopower generation ([19]; see also Table 3). The average farm size in China is between 0.5 and $1.0 \mathrm{~h} \mathrm{~m}^{-2}$ per household [61,62]. Further, households in less well developed areas largely use their farmland for crops as needed by the household rather than having a single cash crop. The required network of suppliers should therefore consist of several 10,000 s of households, and even several 100,000 s of households in less well developed areas.

\subsubsection{Fuel cost}

A number of previous studies have reported sharp increases in biomass residue cost with the increased utilization by biomass power projects $[16,60,63]$, and data from CDM applications shows a similar trend (Fig. 8). Data suggests average fuel prices have plateaued around $35 € \mathrm{t}^{-1}$ in recent years, although other reports claim prices of up to $42 € \mathrm{t}^{-1}$ in some regions $[16,63,64]$. Furthermore, longer term increases in prices remain likely. The price for these resources is determined by the prices paid for competing uses (Table 3), as well as the labor and fuel use for collection and delivery of the resources. The total number of animals kept in China's animal husbandry sectors is rapidly expanding, increasing future feed demand [19]. Cost of the fuel consumed during collection and transport of the biomass resources are also likely to continue to rise. Lastly, with increasing rural economic development, labor cost should be expected to keep increasing as well.

\subsubsection{Heat sales revenue}

The combined generation heat and power (CHP) can significantly increase revenue of a biomass power project. A boiler can supply significant amounts of (waste) heat without significant increases in fuel consumption. CHP is a welldeveloped form of biopower in the Northern European countries $[41,42]$. Heat is not easily transported over long distances, however, and therefore needs to be supplied to local district heating networks or industrial processes [41,42].

In China, the average price for the supply of heat is $4.1 € \mathrm{GJ}^{-1}$ (incl. VAT) [33]. There are no government subsidies for heat from biopower. A typical $30 \mathrm{MW}$ biopower project in China supplies circa 750,000 GJ $\mathrm{y}^{-1}$ [33]. At those average levels of price and of supply, heat sales can increase revenue by approximately circa $22 \%$. The contribution of heat sales and other sources of revenue for a typical project is presented in Fig. 9.

However, around two-thirds of currently operational projects and an even larger share of planned projects have failed to find demand for heat supply (Fig. 10). Interviewees, as well as many CDM applications indicated that this was due to a lack of existing centralized infrastructure or limited demand for heat and steam [33].

\subsubsection{Carbon credit sales}

Chinese GHG emission reduction projects are eligible for registration as a $C D M$ project and may trade the resulting carbon credits 'CER' (certified emission reduction) in international markets. The large majority of Chinese biomass projects has registered or is requesting registration as a CDM project (Fig. 10).

Between 2009 and 2012, CER futures have traded for approximately $12 € \mathrm{t}^{-1} \mathrm{CO}_{2}$-eq [65], and forecasts have long 


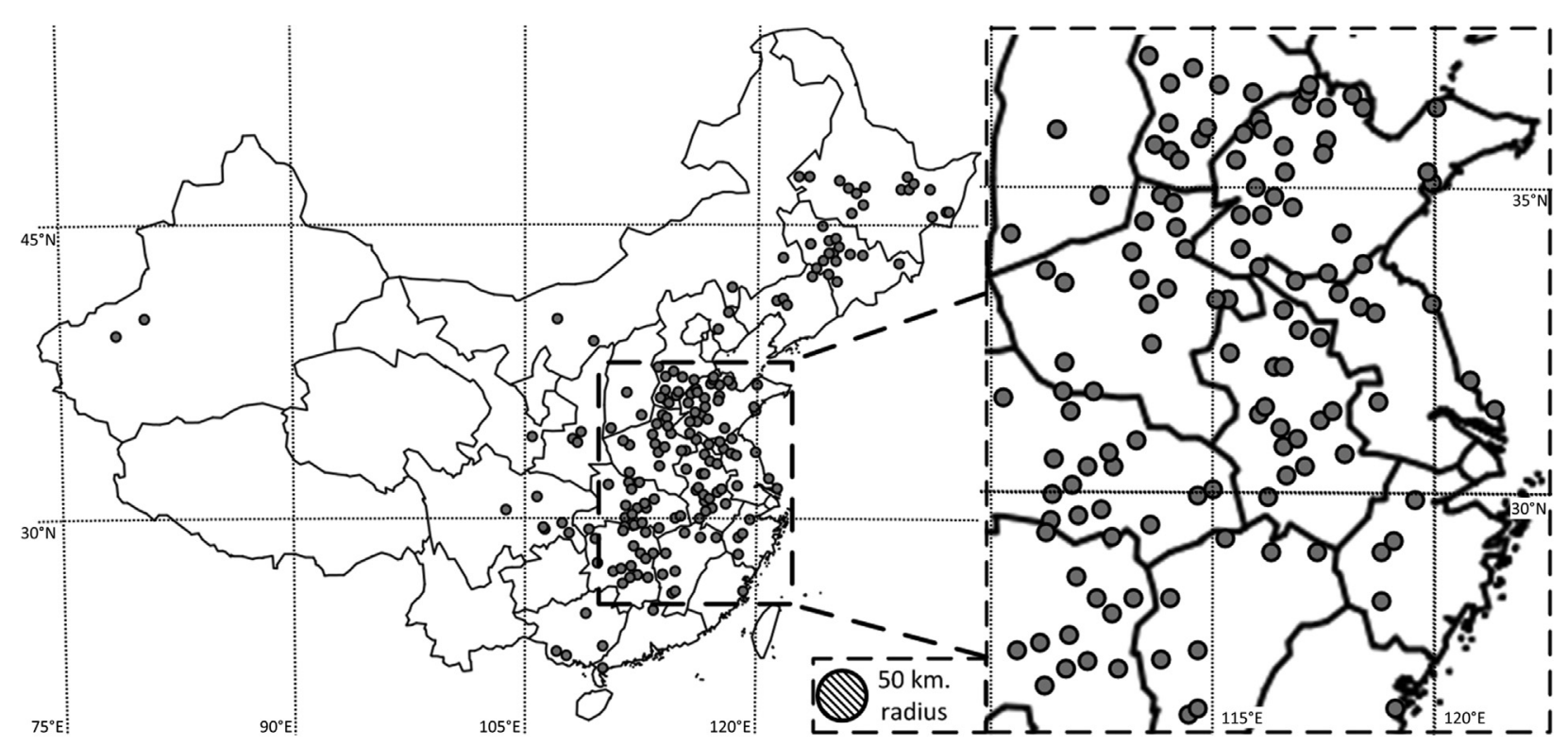

Fig. 7 - Location of biopower projects in China. Notes: includes both operational and planned projects; the $50 \mathrm{~km}$ radius is the suggested exclusive resource collection area, see also Section 3.4 .1 ; the $50 \mathrm{~km}$ radius is scaled for the blown-up, right hand section of the map. Data source: [33].

suggested stable or rising CER prices over the period until 2020 $[65,66]$. CDM applications for Chinese biopower projects have assumed a CER value of circa $9 € \mathrm{t}^{-1} \mathrm{CO}_{2}$-eq on average, which equates to $7.75 € \mathrm{MWh}^{-1}$. Contribution of CER income to lifetime revenue for a typical biopower project is included in Fig. 9.

Carbon markets in the EU, the largest active carbon trading market, has suffered from strong oversupply, however [67]. To curb supply, the European Parliament has decided that CER from CDM projects registered from Jan. 1st 2013 onwards cannot be exchanged with EUA (European emissions allowance), i.e., cannot be used to offset emission reduction obligations in the EU (with the exception of CER from the 'Least Developed Economies') [68]. Outside of the EU market global CER prices have slumped to as low as $0.30 € \mathrm{t}^{-1} \mathrm{CO}_{2}$-eq [69],

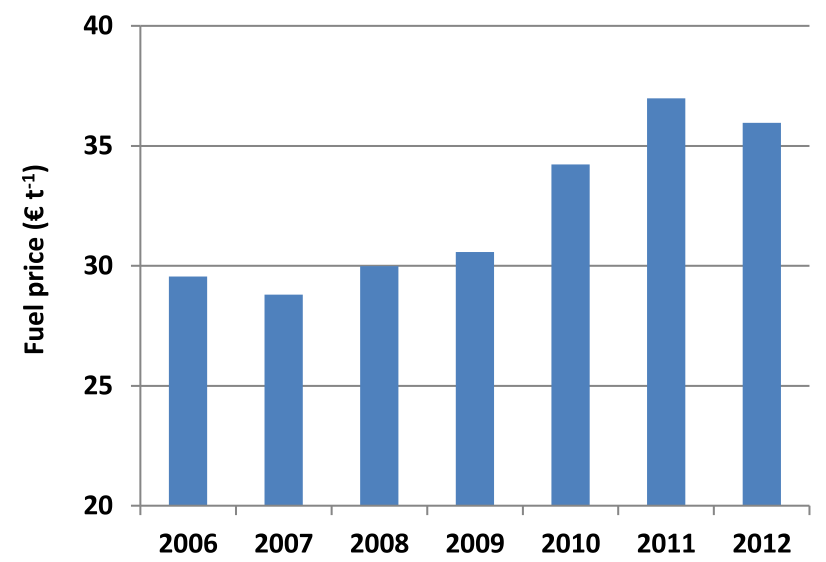

Fig. 8 - Crop and forestry residue prices in China. Note: prices based on wet basis; prices are averages for a variety of different residues; VAT incl. Data source: [33]. with little expectation of strong improvement in the period until 2020 [69,70]. This has strongly impacted Chinese CDM applications. In both 2011 and 2012, around 1000 Chinese CDM applications were submitted (all project types); in 2013, only 43 new applications were submitted [71]. China is currently piloting domestic trading schemes for carbon emissions, but national coverage and strongly increased demand may be many years away [72].

\subsection{Investment outlook: NPV and minimum feed-in-} tariff needed to spur investment

Here, results from Sections 3.1-3.5 are combined to calculate the current Net Present Value of new biomass power projects, as well as the minimum level of Feed-In-Tariff required to keep NPV positive.

3.6.1. Net Present Value of new investment in biomass power A discounted cash flow model for a typical biomass power project was made, against an internal rate of return of $8 \%$. The values used for the main financial and operational parameters in the estimation of this Net Present Value (NPV) have been derived in Sections 3.1-3.5, but a summary overview is provided in Appendix A. A number of parameters included in this full list in Appendix A have not been dealt with in detail in Sections 3.1-3.5. These have been derived from project files as included in the project database (included in the Supplementary material). The estimation of NPV includes a range of values for fuel price, capacity factor, and whether or not the projects' developers manage to find demand for the supply of heat and/or carbon credits (Fig. 11).

It appears that either the supply of heat or carbon credits is sufficient to keep project NPV above zero over the entire range of fuel prices used. However, with the current lack of demand 


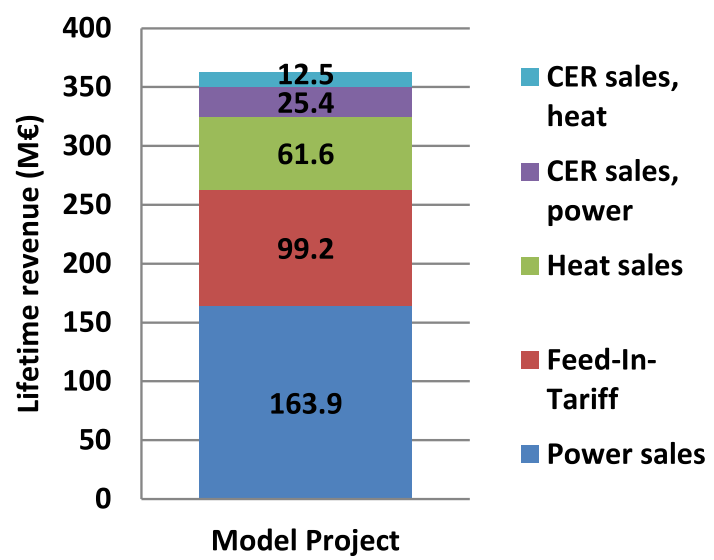

Fig. 9 - Lifetime revenue of a typical biopower project, by revenue source. Notes: revenue incl. VAT; assumptions: see Appendix A.

for carbon credits from China, and with difficulties for most projects to find demand for heat supply, it is the bottom three lines in Fig. 11 that are most relevant. At a capacity factor of $55 \%$ (average of all operational plants), 62\% (as assumed in CDM applications), and even at a high capacity factor of $68 \%$ (as targeted by policy), the NPV is below zero at current biomass fuel prices (Fig. 11).

This estimated lack of attractiveness of current investment in biomass power projects is not merely a theoretical issue. These problems already appear to have had an effect on biopower plant operators and development plans. Kaidi reported a gross profit of $11.0 \mathrm{M} €$ for its biomass arm over 2011, but a gross loss of $4.6 \mathrm{M} €$ in 2012, despite an increase in the number of operational plants [25]. From 2011 through 2013, Kaidi completed construction on 19 biopower plants [26]. Kaidi initially had plans for at least another 26 more plants [33], but has not started construction on a single new project between March 2012 and March 2014 [26,73]. Unfortunately, NBE is not publicly traded and therefore does not publish publicly available annual reports. The amount of 'planned' projects reported in Fig. 1, however, likely contain a large share of projects that have been canceled and this number is therefore over-optimistic, in particular seen Kaidi's share in future development plans (Fig. 2).

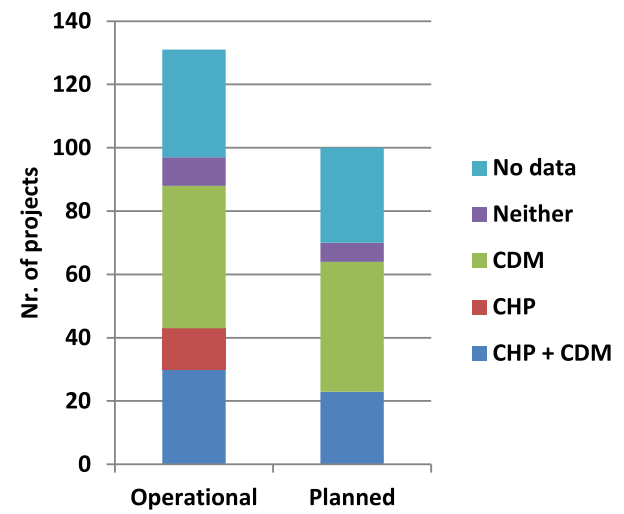

Fig. 10 - Nr. of biopower projects supplying heat or CDM credits. Source: [33].

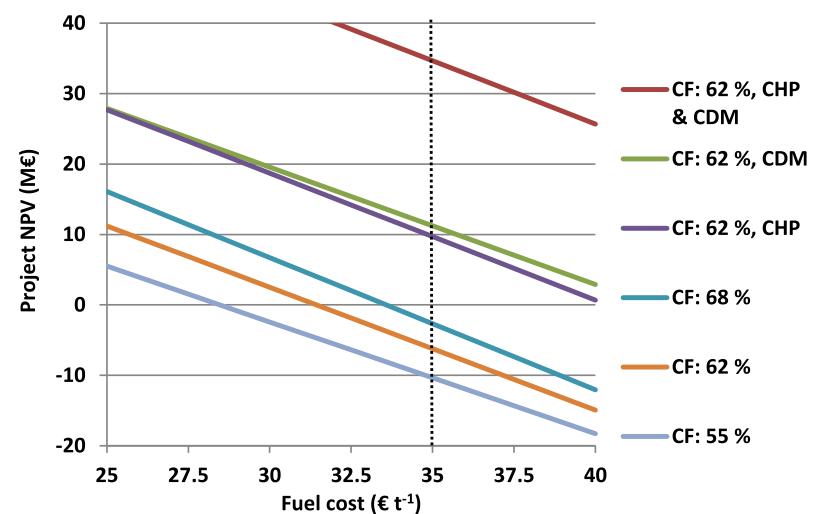

Fig. 11 - NPV of a model biopower project in China. Notes: CF: Capacity Factor; CHP: project sells heat and power; CDM: project supplies CER; assumptions: see Appendix A; dashed line is approximate current fuel cost (see also Fig. 8).

3.6.2. Minimum feed-in-tariff required to spur biomass power investment

Using the same NPV model, the minimum Feed-in-Tariff (FIT) required to keep project NPV positive was calculated. As can be deduced from results in Fig. 11, the current FIT of $90.9 € \mathrm{MWh}^{-1}$ is sufficient for projects that manage to derive revenue from sales of either heat or CER, within the entire range of expected values for capacity factor and fuel prices. In the most likely scenario that no revenue from these sources can be secured, the FIT needs to be at least 97 to $105 € \mathrm{MWh}^{-1}$ to keep NPV positive, depending on capacity factor and fuel price (Fig. 12).

\section{Discussion and policy recommendations}

The accuracy of the Net Present Value of biomass power projects in China, as reported in this study is mostly

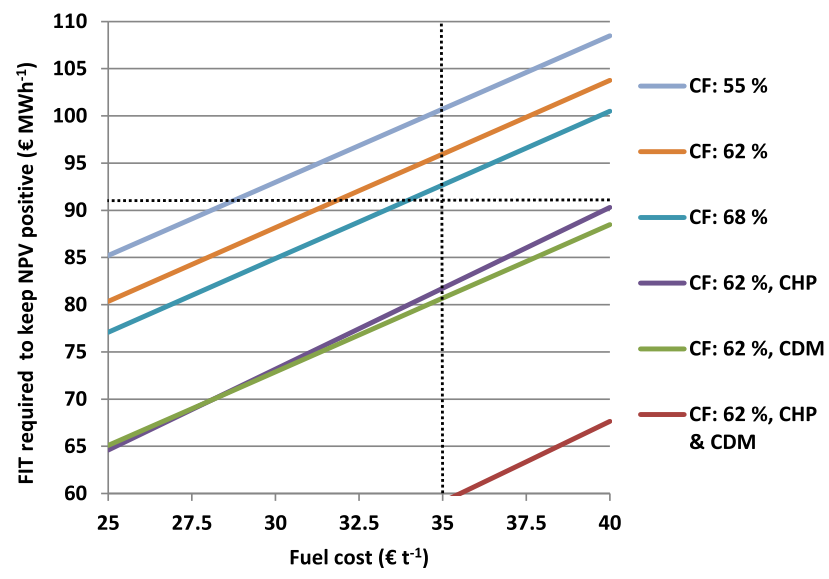

Fig. 12 - FIT at which model biopower project NPV equals zero. Notes: CF: Capacity Factor; CHP: project sells heat and power; CDM: project supplies CER; assumptions: see Appendix A; dashed line indicate current FIT level and approximate current fuel cost (see also Fig. 8). 
dependent on the estimates of the following parameters: construction cost, fuel price, capacity factor, revenue from carbon credit and heat sales.

The estimates of construction and fuel cost are derived as averages from a large number of publicly available and externally audited project files (the CDM registry; [22]). The estimated construction cost of $1150 € \mathrm{~kW}^{-1}$ is in line with values reported by earlier work. A number of earlier studies have suggested 1100 to $1300 € \mathrm{~kW}^{-1}$ for foreign technology versus 785 to $910 € \mathrm{~kW}^{-1}$ for domestic technology $[17,18,64,74,75]$. Although a small number of projects in the overview presented in Fig. 5 do indeed report values as low as 750 to $900 € \mathrm{~kW}^{-1}$, there is a clear convergence towards the $1150 € \mathrm{~kW}^{-1}$ mark, for projects using either domestic or foreign technology.

Estimates on fuel cost are entirely in line with earlier reports. Estimates have suggested costs of as low as 18 to $24 € \mathrm{t}^{-1}$ prior to circa $2010[18,76]$, but there is general consensus that prices have risen to around $35 € \mathrm{t}^{-1}$ or even higher in recent years [75-77]. Zhao and Yan do note that price differences remain between China's regions, of between 27 and $42 € \mathrm{t}^{-1}$ [64].

The capacity factors used in this report are derived from government reports on payments to individual projects, and there is little reason to assume these would be underreported.

Data is also consistent with reports by a recipient of the subsidies, Wuhan Kaidi [24]. Although a number of earlier studies have indicated problems with poor technological performance, these have not reported the extent of these problems in an estimate of availability or capacity factor $[59,76]$.

The current problems with securing additional revenue via sales of carbon emissions permits or through the sales of heat have been discussed in Sections 3.5.3 and 3.5.4. As the assumption in our estimate is that no revenue is obtained from these sources, this requires little further comparison with estimates from earlier reports.

Lastly, in the estimates of NPV and required Feed-In-Tariff, scenarios have further incorporated a range of fuel prices and capacity factors, which cover the low to high end of estimates on the value of these parameters as reported in this study, as well as earlier reports.

Taken together, and assuming a minimum internal rate of return of $8 \%$, investors would want to see revenue of between 97 and $105 € \mathrm{MWh}^{-1}$ before investing in biopower projects. Liu and colleagues [17] reported a rough estimate of $54-108 € \mathrm{MWh}^{-1}$ in a study that compared several renewable energy technologies. Zhao and colleagues reported a single estimate of $79 € \mathrm{MWh}^{-1}$ [16], and Mang reports a range of 85-97 $€ \mathrm{MWh}^{-1}$ [77]. These estimates should be somewhat lower than those made in this study, as these studies all reported pure generation costs, i.e., at zero profit. It is not immediately clear what levels of fuel cost and/or capacity factors were used in deriving these estimates and further comments on comparability is therefore difficult.

The simplest policy solution to ensure reasonable profitability in the sector, then, would be to increase the Feed-InTariff, from the current $91 € \mathrm{MWh}^{-1}$, to levels of between 97 and $105 € \mathrm{MWh}^{-1}$. In national currency this equates to 800 to $865 \mathrm{CNY} \mathrm{MWh}^{-1}$, up from the current level of $750 \mathrm{CNY} \mathrm{MWh}^{-1}$.
Instead of an increased FIT, profit levels may also be improved through exceptions in corporate income tax or VAT. Such exceptions, and their extent, may be made conditional on fuel prices and/or whether or not individual projects manage to secure revenue from heat sales. Such a conditional system would be better organized via income tax or VAT because this requires sufficient insight into individual projects finances. The Ministry of Finance and its State Administration of Taxation can be expected to have such insight, whereas grid operators, which currently distribute the FIT payments, may not.

Governmental organizations may also help encourage heat utilization. Local governments may have a key role in organizing heat demand from biomass power projects in local industrial parks or residential heating networks. This, too, may also require a financial incentive, e.g., canceling VAT over heat from renewable resources.

There is also a need for more dependable fuel supply networks. Local rural energy bureaus may be the most suited organization to assist operators with this task, as they have well developed relationships with local farming communities for a variety of other government programmes. Experiences and best practices in doing so could be disseminated via provincial or national networks of local bureaus.

Functional fuel supply networks are most needed in the vicinity of biopower projects, but could also be set up in areas more remote from biomass power projects. Fuel collection stations could collect crop wastes and process these into briquettes or pellets, to be used locally, in household stoves, or transported to more remote fuel markets. Networks of collection station could grow out to provincial or national levels, and even be integrated with international markets for pelletized fuels. Such a supply network can help mitigate seasonal or local fuel shortages and price fluctuations, reducing supply risks for biopower plan operators.

\section{Conclusion}

Chinese policy ambitions to develop biopower have been successful to a certain extent. The establishment of a Feed-InTariff, combined with a number of ambitious project developers, has ensured relatively rapid growth of the pathway of direct firing of crop and forestry residues. Installations have grown to circa $1 \mathrm{GW}$ of annual additions, and an increasing number of project developers and boiler manufacturers have entered the market.

In order to continue to promote investment in the sector, however, Feed-In-Tariffs should be increased to levels of between 97 and $105 € \mathrm{MWh}^{-1}$, so that future investments remain reasonably profitable. A number of developments have affected the investment outlook for biopower projects, and without an increased FIT, growth should be expected to stall. Fuel prices have rapidly risen, local competition over biomass resources appears to be affecting fuel availability, operational performance of power plants has remained behind on expectations, and carbon markets are no longer providing a much needed additional source of revenue. It is entirely unlikely that these parameters will improve within the foreseeable future. No significant further reductions in construction costs are to be expected, neither global nor 
domestic carbon markets are going to improve significantly within the next few years, and fuel prices are more likely to rise than to fall.

\section{Acknowledgments}

The author gratefully acknowledges financial support in the form of a Foreign Student Scholarship from the Graduate University of the Chinese Academy of Sciences, from the Chalmers Environmental Initiative, grant nr. 4741311, and from the Chalmers SYS - Innovationssystem project, grant nr. 99531.

\section{Appendix A. Supplementary data}

Supplementary data related to this article can be found at http://dx.doi.org/10.1016/j.biombioe.2014.12.014.

\section{Appendix B. Main parameter assumptions for NPV calculation of a model biopower project}

\begin{tabular}{|c|c|c|}
\hline Parameter & Value & Unit \\
\hline \multicolumn{3}{|l|}{ General } \\
\hline Installed capacity & 30 & MW \\
\hline Capacity factor & 62.4 & $\%$ \\
\hline Net power generation & 163,987 & MWh $\mathrm{yr}^{-1}$ \\
\hline Heat supply (if CHP) & 750,000 & $\mathrm{GJ} \mathrm{yr}^{-1}$ \\
\hline Technical lifetime & 20 & yr \\
\hline \multicolumn{3}{|l|}{ Revenue } \\
\hline Electricity tariff, years $1-15$, VAT incl. & 90.9 & $€ \mathrm{MWh}^{-1}$ \\
\hline Electricity tariff, years $16-20$, VAT incl. & 50.3 & $€ \mathrm{MWh}^{-1}$ \\
\hline Heat price, VAT incl. & 4.1 & $€ \mathrm{GJ}^{-1}$ \\
\hline \multicolumn{3}{|l|}{ Investment } \\
\hline Construction cost & 1,150 & $€ \mathrm{~kW}^{-1}$ \\
\hline Static total investment & $35,500,000$ & $€$ \\
\hline Construction interest & $1,104,000$ & $€$ \\
\hline Discount rate & 8 & $\%$ \\
\hline \multicolumn{3}{|l|}{$\mathrm{O} \& \mathrm{M}$} \\
\hline Fuel consumption (pure electric) & 1.50 & $\mathrm{t} \mathrm{MWh}^{-1}$ \\
\hline Fuel consumption (CHP) & 1.65 & $\mathrm{t} \mathrm{MWh}^{-1}$ \\
\hline Water and other material cost & 275,000 & $€ \mathrm{yr}^{-1}$ \\
\hline Maintenance ( $2.5 \%$ of investment) & 845,595 & $€ \mathrm{yr}^{-1}$ \\
\hline Staff & 525,000 & $€ \mathrm{yr}^{-1}$ \\
\hline Other & 350,000 & $€ \mathrm{yr}^{-1}$ \\
\hline \multicolumn{3}{|l|}{ Taxes } \\
\hline $\begin{array}{l}\text { VAT: electricity, CER, equipment, } \\
\text { maintenance }\end{array}$ & 17 & $\%$ \\
\hline VAT: heat, biomass fuel, water & 13 & $\%$ \\
\hline Income tax, yrs $1-3$ & 0 & $\%$ \\
\hline Income tax, yrs 4-6 & 12.5 & $\%$ \\
\hline Income tax, yrs $7-20$ & 25 & $\%$ \\
\hline \multicolumn{3}{|l|}{ CER } \\
\hline CER price, VAT incl. & 9 & $€ \mathrm{t}^{-1}$ \\
\hline Exchange rate $€: \mathrm{CNY}$ & 8.25 & $\mathrm{n} / \mathrm{a}$ \\
\hline Grid emission factor electricity $\left(\mathrm{CO}_{2}\right.$-eq) & 0.893 & $\mathrm{t} \mathrm{MWh}^{-1}$ \\
\hline Grid emission factor heat $\left(\mathrm{CO}_{2}\right.$-eq) & 0.0955 & $\mathrm{tGJ}^{-1}$ \\
\hline Crediting period & $3 \times 7$ & yr \\
\hline
\end{tabular}

\section{R E F E R E N C E S}

[1] National Energy Administration. 12th five year plan for renewable energy. original in Chinese [Internet]. Beijing: National Energy Administration; 2012 [cited 2014 Dec 8]. Available from:, http://www.gov.cn/zwgk/2013-01/23/ content_2318554.htm.

[2] REN21 (Renewable energy policy network for the 21st century). Renewables 2013 global status report [Internet]. Paris: REN21 Secretariat; 2013 [cited 2014 Dec 8]. Available from: http://www.ren21.net/ren21activities/ globalstatusreport.aspx.

[3] Xingang Z, Jieyu W, Xiaomeng L, Pingkuo L. China's wind, biomass and solar power generation: what the situation tells us? Renew Sustain Energy Rev 2012;16(8):6173-82.

[4] Hong L, Zhou N, Fridley D, Raczkowski C. Assessment of China's renewable energy contribution during the 12th five year plan. Energy Pol 2013;62:1533-43.

[5] Zhang X, Chang S, Martinot E. Renewable energy in China: an integrated technology and policy perspective. Energy Pol 2012;51:1-6.

[6] Wang Q. Effective policies for renewable energy - the example of China's wind power-lessons for China's photovoltaic power. Renew Sustain Energy Rev 2010;14(2):702-12.

[7] Xingang Z, Xiaomeng L, Pingkuo L, Tiantian F. The mechanism and policy on the electricity price of renewable energy in China. Renew Sustain Energy Rev 2011;15(9):4302-9.

[8] Hu Z, Wang J, Byrne J, Kurdgelashvili L. Review of wind power tariff policies in China. Energy Pol 2013;53:41-50.

[9] Yang M, Nguyen F, De T'Serclaes P, Buchner B. Wind farm investment risks under uncertain CDM benefit in China. Energy Pol 2010;38(3):1436-47.

[10] Liu X. The value of holding scarce wind resource-a cause of overinvestment in wind power capacity in China. Energy Pol 2013;63:97-100.

[11] Liu J, Goldstein D. Understanding China's renewable energy technology exports. Energy Pol 2013;52:417-28.

[12] Wang Z, Qin H, Lewis JI. China's wind power industry: policy support, technological achievements, and emerging challenges. Energy Pol 2012;51:80-8.

[13] Gosens J, Lu Y. From lagging to leading? Technological innovation systems in emerging economies and the case of Chinese wind power. Energy Pol 2013;60:234-50.

[14] Ru P, Zhi Q, Zhang F, Zhong X, Li J, Su J. Behind the development of technology: the transition of innovation modes in China's wind turbine manufacturing industry. Energy Pol 2012;43:58-69.

[15] de la Tour A, Glachant M, Ménière Y. Innovation and international technology transfer: the case of the Chinese photovoltaic industry. Energy Pol 2011;39(2):761-70.

[16] Xingang Z, Zhongfu T, Pingkuo L. Development goal of $30 \mathrm{GW}$ for China's biomass power generation: will it be achieved? Renew Sustain Energy Rev 2013;25:310-7.

[17] Liu T, Xu G, Cai P, Tian L, Huang Q. Development forecast of renewable energy power generation in China and its influence on the GHG control strategy of the country. Renew Energy 2011;36(4):1284-92.

[18] GIEC (Guangzhou Institute of Energy Conversion - Chinese Academy of Sciences). Consultation on biomass power generation technology improvement [Internet]. Guangzhou: China Renewable Energy Scale-up Program (CRESP); 2005 [cited 2014 Dec 8]. Available from: http://www.cresp.org.cn/ uploadfiles/89/611/biomass_power_generation_biomass_ power_generation_en.pdf. 
[19] ERI (Energy research institute; NDRC. Study on China biomass Energy technology development roadmap [Internet]. Beijing: ERI, NDRC; 2010 [cited 2014 Dec 8]. Available from: http://www.understandchinaenergy.org/wpcontent/uploads/2013/10/ERI-NRDC-Biomass-TechnologyDevelopment-Roadmap.pdf.

[20] Remer DS, Nieto AP. A compendium and comparison of 25 project evaluation techniques. Part 1: net present value and rate of return methods. Int J Prod Econ 1995;42(1):79-96.

[21] State Power Corporation of China. Interim rules on economic assessment of electrical engineering retrofit projects (trial) [2002] No.623 [translated online version] [Internet]. Beijing: China Electric Power Publications; 2002 [cited 2014 Dec 10]. Available from:, https://cdm.unfccc.int/Projects/DB/TUEVRHEIN1187936755.18/ReviewInitialComments/ F1R7ZDXODSPH8Z41R9LPSPWZK5TL4Z.

[22] UNFCCC. CDM registry [Internet]. Bonn: UNFCCC; 2013 [cited 2014 Dec 8]. Available from: cdm.unfccc.int/Projects/ projsearch.html.

[23] NDRC. List of renewable energy projects power price premiums [several editions used] [Original in Chinese] [Internet]. Beijing: NDRC; 2011 [cited 2014 Dec 8]. Available from:, http://www.sdpc.gov.cn/fzgggz/jggl/zcfg/201212/ t20121204_517159.html.

[24] Wuhan Kaidi Electrical Power Co. Ltd. Report on operational capacity during May of 2013 [Original in Chinese] [Internet]. Wuhan: Wuhan Kaidi Electrical Power Co. Ltd.; 2013 [cited 2014 Dec 8]. Available from:, http://www.china-kaidi.com/ touzhi_detail/\&downloadsId=55.html.

[25] Wuhan Kaidi Electrical Power Co. Ltd. Annual report 2012 [Original in Chinese] [Internet]. Wuhan: Wuhan Kaidi Electrical Power Co. Ltd.; 2013 [cited 2014 Dec 8]. Available from:, http://www.china-kaidi.com/touzhi_list/ \&downloadcategoryid=3\&isMode=false.html.

[26] Wuhan Kaidi Electrical Power Co. Ltd. Half-year report 2013 [Original in Chinese] [Internet]. Wuhan: Wuhan Kaidi Electrical Power Co. Ltd.; 2013 [cited 2014 Dec 8]. Available from:, http://www.china-kaidi.com/touzhi_list/ \&downloadcategoryid=3\&isMode=false.html.

[27] ECB. Euro foreign exchange reference rates, Chinese Yuan renminbi (CNY) [Internet]. Brussels: ECB; 2014 [cited 2014 May 23]. Available from: https://www.ecb.europa.eu/stats/ exchange/eurofxref/html/eurofxref-graph-cny.en.html.

[28] National Bureau of Statistics. China statistical yearbook 2013 edition [Internet]. Beijing: China Statistics Press; 2013 [cited 2014 May 23]. Available from: http://www.stats.gov.cn/tjsj/ ndsj/2013/indexeh.htm.

[29] Wang F, Yin H, Li S. China's renewable energy policy: commitments and challenges. Energy Pol 2010;38(4):1872-8.

[30] NDRC. Medium and long-term development plan for renewable Energy (unofficial translated version) [Internet]. Beijing: NDRC; 2007 [cited 2014 Dec 8]. Available from: http:// www.martinot.info/China_RE_Plan_to_2020_Sep-2007.pdf.

[31] NDRC. Renewable energy price and cost-sharing management, pilot scheme (NDRC price, 2006, nr. 7) [original in Chinese] [Internet]. Beijing: NDRC; 2006 [cited 2014 Dec 8]. Available from:, http://www.sdpc.gov.cn/fzgggz/jggl/zcfg/ 200601/t20060120_57586.html.

[32] NDRC. Notice on electricity price adjustment (NDRC price 2011, nr. 2618-2623) [Original in Chinese] [Internet]. Beijing: NDRC; 2011 [cited 2014 Dec 8]. Available from:, http://www.sdpc.gov. cn/zwfwzx/zfdj/jggg/dian/201112/t20111201_448622.html.

[33] Gosens J. Author's database of biomass power projects in China: appended as supplementary material with the electronic version of this article; see method section for sources used in compiling this database.

[34] NDRC. Improvement of pricing policy for agriculture and forestry biomass power. NDRC Price 2010, nr. 1579 [Original in Chinese] [Internet]. Beijing: NDRC; 2010 [cited 2014 Dec 8]. Available from:, http://www.sdpc.gov.cn/zwfwzx/zfdj/jggg/ dian/201007/t20100728_363366.html.

[35] MEP (Ministry of Environmental Protection). Strengthening the environmental impact assessment management of biomass power generation projects. MEP [2008] nr. 82 [Original in Chinese] [Internet]. Beijing: MEP; 2008 [cited 2014 Dec 8]. Available from:, http://www.mep.gov.cn/gkml/hbb/ bwj/200910/t20091022_174611.htm.

[36] NDRC. Management of the construction of biomass power generation projects. NDRC Energy [2010], nr. 1803 [Original in Chinese] [Internet]. Beijing: NDRC; 2010 [cited 2014 Dec 8]. Available from:, http://nyj.ahpc.gov.cn/info.jsp?xxnr_ $\mathrm{id}=10082643$.

[37] Liu G, Huang M. Fuel collecting radius and installed capacity of straw stalk power plant [in Chinese] Electr Power Constr 2011;32(3):72-5.

[38] MOA (Ministry of Agriculture). Development plan for the agricultural bioenergy industry 2007-2015 [Original in Chinese] [Internet]. Beijing: MOA; 2007 [cited 2014 Dec 8]. Available from:, http://www.moa.gov.cn/zwllm/ghjh/200808/ t20080826_1168529.htm.

[39] Gosens J, Lu Y. Prospects for global market expansion of China's wind turbine manufacturing industry. Energy Pol 2014;67:301-18.

[40] Shen X. Providing biopower to the dragon \& the world. Bioenergy Int 2010;47(6):17-8.

[41] Faaij APC. Bio-energy in Europe: changing technology choices. Energy Pol 2006;34(3):322-42.

[42] IEA. Biomass for power generation and CHP [Internet]. Paris: IEA; 2007 [cited 2014 Dec 8]. Available from: http://www.iea. org/techno/essentials3.pdf.

[43] REN21 (Renewable enery policy network for the 21st century). Renewables 2012 global status report [Internet]. Paris: REN21 Secretariat; 2012 [cited 2014 Dec 8]. Available from: http://www.ren21.net/ren21activities/ globalstatusreport.aspx.

[44] Lamers P, Junginger M, Hamelinck C, Faaij A. Developments in international solid biofuel trade-an analysis of volumes, policies, and market factors. Renew Sustain Energy Rev 2012;16(5):3176-99.

[45] RWE AG. Tilbury biomass power station [Internet]. Swindon: RWE AG; 2013 [cited 2014 Dec 8]. Available from: http://www. rwe.com/web/cms/en/97606/rwe-npower/about-us/ourbusinesses/power-generation/tilbury/.

[46] Drax Group plc. Our biomass plans [Internet]. Yorkshire: Drax Group plc; 2013 [cited 2014 Dec 8]. Available from: http://www.drax.com/biomass/our-biomass-plans/.

[47] Roos JA, Brackley AM. Asian markets for Wood pellets [Internet]. Washington: United States Department of Agriculture; 2013 [cited 2014 Dec 8]. Available from: http:// www.fs.fed.us/pnw/pubs/pnw_gtr861.pdf.

[48] Obernberger I. Decentralized biomass combustion: state of the art and future development. Biomass Bioenergy 1998;14(1):33-56.

[49] Demirbas A. Potential applications of renewable energy sources, biomass combustion problems in boiler power systems and combustion related environmental issues. Prog Energy Combust Sci 2005;31(2):171-92.

[50] Saidur R, Abdelaziz EA, Demirbas A, Hossain MS, Mekhilef S. A review on biomass as a fuel for boilers. Renew Sustain Energy Rev 2011;15(5):2262-89.

[51] Yin C, Rosendahl LA, Kær SK. Grate-firing of biomass for heat and power production. Prog Energy Combust Sci 2008;34(6):725-54.

[52] Latest development of CFB boilers in China. In: Yue G, Yang H, Lu J, Zhang H, editors. Proceedings of the 20th international conference on fluidized bed combustion; 2009 
May 18-21. Xian, China: Tsinghua University Press, Beijing and Springer-Verlag, Berlin Heidelberg; 2010.

[53] Michelsen HP, Frandsen F, Dam-Johansen K, Larsen OH. Deposition and high temperature corrosion in a $10 \mathrm{MW}$ straw fired boiler. Fuel Process Tech 1998;54(1-3):95-108.

[54] Chatzimouratidis AI, Pilavachi PA. Technological, economic and sustainability evaluation of power plants using the analytic hierarchy process. Energy Pol 2009;37(3):778-87.

[55] China Electric Power Press. China electric power yearbook [several years used] [Original in Chinese]. Beijing: China Electric Power Press; 2013.

[56] US-EIA (US Energy Information Administration). Electric power annual [Internet]. Washington: US-EIA; 2013 [cited 2014 Dec 8]. Available from: http://www.eia.gov/electricity/ annual/.

[57] CWEA (Chinese Wind Energy Association). China wind power outlook 2012 [Internet]. Beijing: CWEA; 2012 [cited 2014 Dec 8]. Available from: http://www.gwec.net/ publications/country-reports/china-wind-energy-outlook2012/.

[58] Zeng X, Ma Y, Ma L. Utilization of straw in biomass energy in China. Renew Sustain Energy Rev 2007;11(5):976-87.

[59] Wu CZ, Yin XL, Yuan ZH, Zhou ZQ, Zhuang XS. The development of bioenergy technology in China. Energy 2010;35(11):4445-50.

[60] K\&W Network. Kai Johan Jiang of dragon power: an entrepreneur's high hopes for China's biomass energy industry [Internet]. Philadelphia: Wharton School of the University of Pennsylvania; 2010 [cited 2014 Dec 8]. Available from: http://knowledge.wharton.upenn.edu/article/kaijohan-jiang-of-dragon-power-an-entrepreneurs-highhopes-for-chinas-biomass-energy-industry/.

[61] MOA. China agriculture statistical report (several years used) [original in Chinese]. Beijing: China Agriculture Press; 2011.

[62] Chen Z, Huffman WE, Rozelle S. Inverse relationship between productivity and farm size: the case of China. Contemp Econ Pol 2011;29(4):580-92.

[63] Zhang Q, Zhou D, Zhou P, Ding H. Cost analysis of strawbased power generation in Jiangsu Province, China. Appl Energy 2013;102:785-93.

[64] Zhao Z-Y, Yan H. Assessment of the biomass power generation industry in China. Renew Energy 2012;37(1):53-60.

[65] Covec. Carbon price forecasts - report prepared for the parliamentary commissioner for the environment of New Zealand [Internet]. Auckland: Covec; 2010 [cited 2014 Dec 8]. Available from: http://www.pce.parliament.nz/assets/ Uploads/Covec-Final-Report-19-07-10.pdf.

[66] Michaelowa A. Scenarios for the global carbon markets paper 1 for the CDM policy dialogue [Internet]. Bonn: CDM Policy Dialogue; 2012 [cited 2014 Dec 8]. Available from: http://www.cdmpolicydialogue.org/research/1030_ scenarios.pdf.

[67] Reuters. Carbon wins lifeline after tight EU parliament vote, Jul. 3rd, 2013 [Internet]. Strasbourg/London: Reuters; 2013 [cited 2014 Dec 8]. Available from: http://www.reuters.com/ article/2013/07/03/eu-carbon-marketidUSL5NOF91UA20130703.

[68] European Parliament and Council. Directive 2009/29/EC of the European Parliament and of the Council of 23 April 2009 amending directive 2003/87/EC so as to improve and extend the greenhouse gas emission allowance trading scheme of the Community. Brussels: European Parliament and Council; 2009.

[69] CDM Policy Dialogue. Climate change, carbon markets and the CDM: a call to action [Internet]. Bonn: CDM Policy Dialogue; 2012 [cited 2014 Dec 8]. Available from: http:// www.cdmpolicydialogue.org/report/rpt110912.pdf.
[70] Reuters UN. carbon price forecasts to 2020 cut further: reuters poll [Internet]. London: Reuters; 2012 [cited 2014 Dec 8]. Available from: http://uk.reuters.com/article/2012/10/02/ us-carbon-poll-idUKBRE89109V20121002.

[71] UNEP/Risoe. CDM Pipeline, online database of CDM projects, update of March 2014 [Internet]. Copenhagen: UNEP/Risoe; 2014 [cited 2014 Dec 8]. Available from: http://www. cdmpipeline.org/.

[72] Jotzo F, De Boer D, Kater H. China carbon pricing survey 2013, China carbon forum [Internet]. Beijing: China Carbon Forum; 2013 [cited 2014 Dec 8]. Available from: http://www. chinacarbon.info/wp-content/uploads/2013/10/ChinaCarbon-Pricing-Survey-2013_Report_English1.pdf.

[73] Wuhan Kaidi Electrical Power Co. Ltd. Half-year report 2012 [Original in Chinese] [Internet]. Wuhan: Wuhan Kaidi Electrical Power Co. Ltd.; 2012 [cited 2014 Dec 8]. Available from:, http://www.china-kaidi.com/touzhi_list/ \&downloadcategoryid=3\&isMode=false.html.

[74] Liu F. Case-based study on biomass combustion power generation in China [Master thesis] [Internet]. Göteborg: Chalmers University of Technology; 2012 [cited 2014 Dec 8]. Available from:, http://publications.lib.chalmers.se/records/ fulltext/183614/183614.pdf.

[75] Hao Y, Luo G. Development of biomass power generation in China: constraints and measures for perfection. Asian Soc Sci 2012;8(15):238-43.

[76] Zhang P, Yanli Y, Yongsheng T, Xutong Y, Yongkai Z, Yonghong Z, et al. Bioenergy industries development in China: dilemma and solution. Renew Sustain Energy Rev 2009;13(9):2571-9.

[77] Mang HP. Biomass power generation in China (online presentation) [Internet]. Kirchberg: German Biogas and Bioenergy Society; 2009 [cited 2014 Dec 8]. Available from: http://www.frankhaugwitz.info/doks/bio/2009_10_China_ Development_biomass_power_technology_Mang_ABRA_ 2009.pdf.

[78] Xinhua News Agency. National Energy administration raises solar PV target again [Original in Chinese] [Internet]. Beijing: China Electricity Council; 2013 [cited 2014 Dec 10]. Available from:, http://www.cec.org.cn/zhengcefagui/2013-01-31/ 96999.html.

[79] EPIA (European Photovoltaic Industry Association). Global market outlook for photovoltaics until 2016 [Internet]. Brussels: EPIA; 2013 [cited 2014 Dec 10]. Available from: http://www.epia.org/news/publications/.

[80] NDRC. 11th five Year plan for renewable energy development, (NDRC Energy 2008, nr. 610) [Original in Chinese] [Internet]. Beijing: NDRC; 2008 [cited 2014 Dec 10]. Available from:, http://www.sdpc.gov.cn/zcfb/zcfbghwb/ 200803/t20080318_579693.html.

[81] NPC (National People's Congress). Renewable energy law (official translated version) [Internet]. Beijing: MOFCOM; 2005 [cited 2014 Dec 10]. Available from: http://english.mofcom. gov.cn/article/policyrelease/questions/201312/ 20131200432160.shtml.

[82] NDRC. Notice on electricity price adjustment (NDRC Price 2006, nrs. 1228-1233) [Original in Chinese]. Beijing: NDRC; 2006 [cited 2014 Dec 10]. Available from:, http://www.sdpc. gov.cn/fzgggz/jggl/jggs/200606/t20060630_129590.html.

[83] MOF. On the adjustment of the renewable energy surcharge, 2013, nr. 89 [Original in Chinese] [Internet]. Beijing: MOF; 2013 [cited 2014 Dec 10]. Available from:, http://zhs.mof.gov. cn/zhengwuxinxi/zhengcefabu/201310/t20131009_996652. html.

[84] NEA (National Energy Administration). Twelfth national fiveyear plan for Energy technology, 2011-2015 [Original in Chinese] [Internet]. Beijing: NEA; 2011 [cited 2014 Dec 10]. Available from:, http://www.nea.gov.cn/131398352_11n.pdf. 